\title{
Seasonal ionic exchange in two-layer canopies and total deposition in a subtropical evergreen mixed forest in central-south China
}

\author{
Gong ZHANG ${ }^{\mathrm{a}, \mathrm{b}}$, Guang Ming ZENG ${ }^{\mathrm{a}}$, Yi Min JIANG ${ }^{\mathrm{a}, \mathrm{b}}$, Guo He HUANG ${ }^{\mathrm{a}}$, Jia Mei YAO ${ }^{\mathrm{c}}$, Ren Jun XIANG ${ }^{\mathrm{d}}$, \\ $\mathrm{Xi}$ Lin ZHANG ${ }^{\mathrm{a}}$ \\ ${ }^{a}$ College of Environmental Science and Engineering, Hunan University, Hunan province, Changsha 410082, China \\ ${ }^{\mathrm{b}}$ Hunan Environmental Protection Bureau, Hunan province, Changsha 410082, China \\ ${ }^{c}$ Xiangya Hospital, Central-south University, Hunan province, Changsha 410083, China \\ ${ }^{\mathrm{d}}$ Hunan Research Academy of Environmental Sciences, Changsha, 410004, China
}

(Received 20 November 2005; accepted 9 March 2006)

\begin{abstract}
About 15 and 9\% of rainfall were intercepted by the top- and sub-canopy layer, respectively. Although seasonal base cations concentrations in the sub-throughfall were higher than those in throughfall, the calculated base cations leached from the sub-canopy was significantly low relative to that in the top-canopy. The uptakes of $\mathrm{H}^{+}$and $\mathrm{NH}_{4}^{+}$in the top-canopy were significantly higher than the sub-canopy, suggesting that the acidity buffering processes mainly took place in the top-canopy. Annual mean dry deposition of $\mathrm{Ca}^{2+}$ accounted for $53.1 \%$ of its annual total deposition, which was higher than that of $\mathrm{Mg}^{2+}(28.2 \%)$ and $\mathrm{K}^{+}(29.8 \%)$. The annual dry deposition of $\mathrm{NH}_{4}^{+}$amounted to $30.6 \%$ of its annual total deposition. The annual total deposition of base cations was similar to the total deposition of inorganic nitrogen $\left(\mathrm{NH}_{4}^{+}-\mathrm{N}, \mathrm{NO}_{3}^{-}-\mathrm{N}\right)$, which were 26.2 and $26.5 \%$ of annual total deposition of all ions, respectively.
\end{abstract}

base cations / nitrogen / throughfall / total deposition / forest

Résumé - Échanges ioniques saisonniers dans deux strates de la canopée et dépôts atmosphériques totaux dans une forêt mixte sempervirente sub-tropicale dans la partie centrale du sud de la Chine. Les strates supérieures et inférieures de la canopée ont intercepté respectivement environ 15 et $9 \%$ des eaux de pluie. Même si les concentrations saisonnières en cations basiques dans les précipitations arrivant au sol (S-TF) étaient plus importantes que celles des précipitations traversant la canopée (TF), le lessivage calculé des cations basiques provenant de la partie inférieure de la canopée était significativement plus faible par rapport à celui de la partie supérieure de la canopée. Le prélèvement de $\mathrm{H}^{+}$et $\mathrm{NH}^{+}$par la partie supérieure de la canopée était significativement supérieur à celui de la partie inférieure de la canopée, ce qui a suggéré que le processus de neutralisation de l'acidité intervenait principalement dans la partie supérieure de la canopée. Les dépôts secs moyens annuels de $\mathrm{Ca}^{2+}$ représentaient $53,1 \%$ de ces dépôts annuels totaux, contre seulement $28,2 \%$ pour $\mathrm{Mg}^{2+}$ et $29,8 \%$ pour $\mathrm{K}^{+}$. Le dépôt sec annuel de $\mathrm{NH}^{4+}$ représentait 30,6\% de son dépôt annuel total. Le dépôt total annuel de cations basiques était similaire au dépôt total d'azote inorganique $\left(\mathrm{NH}_{4}^{+}-\mathrm{N}, \mathrm{NO}_{3}^{-}-\mathrm{N}\right)$ qui représentaient respectivement $26,2 \%$ et $26,5 \%$ du dépôt total annuel de tous les ions.

cations basiques / azote / précipitations traversant la canopée / dépôt total / forêt

\section{INTRODUCTION}

Chemistry of throughfall and stemflow can be significantly modified by forest canopy $[1,10,11,41]$. Forest canopy in the leaching and uptake processes usually acts as the 'sink' and 'source' as well as the 'inert sampler' [2, 4, 9, 29, 39]. Some literatures suggest that the canopy exchange processes depend on: (a) the duration, quantity and acidity of precipitation [23, 32,33], (b) the species and ecological settings [37,47], and (c) forest soil characteristics, such as extractable amount of base cations and soil types $[3,6,31]$. The relative importance of these factors differs among chemical species and forest types and varies seasonally as a result of changes in canopy leaf area and physiological activity $[2,28,36]$.

\footnotetext{
* Corresponding author: zgming@ hnu.cn
}

Fan et al. [17] found that basic cations in throughfall derived mainly from dry deposition and the canopy leaching process was affected by rainwater acidity, and Fan and Hong [18] also reported an active canopy uptake process for $\mathrm{NH}_{4}^{+}$in the fir plantations in Fujian province, southeast China. Hamburg et al. [21] and Lin et al. [24,25] reported that canopy exchange processes were strongly impacted by typhoon. Throughfall chemistry was also affected with high variability in rain forest in Taiwan [21,24, 25].

Although canopy-atmosphere interactions have been reported in temperate forests $[1,5,14,29,42]$, few or limited number of the studies on canopy exchange processes have been conducted in Chinese forests recently, particularly in subtropical forests $[18,25,26]$.

Many forest studies in southwest China reported that acid rain has caused drastic damage to local forest productivity $[22,45]$. Hunan province (central-south China) has a typical 


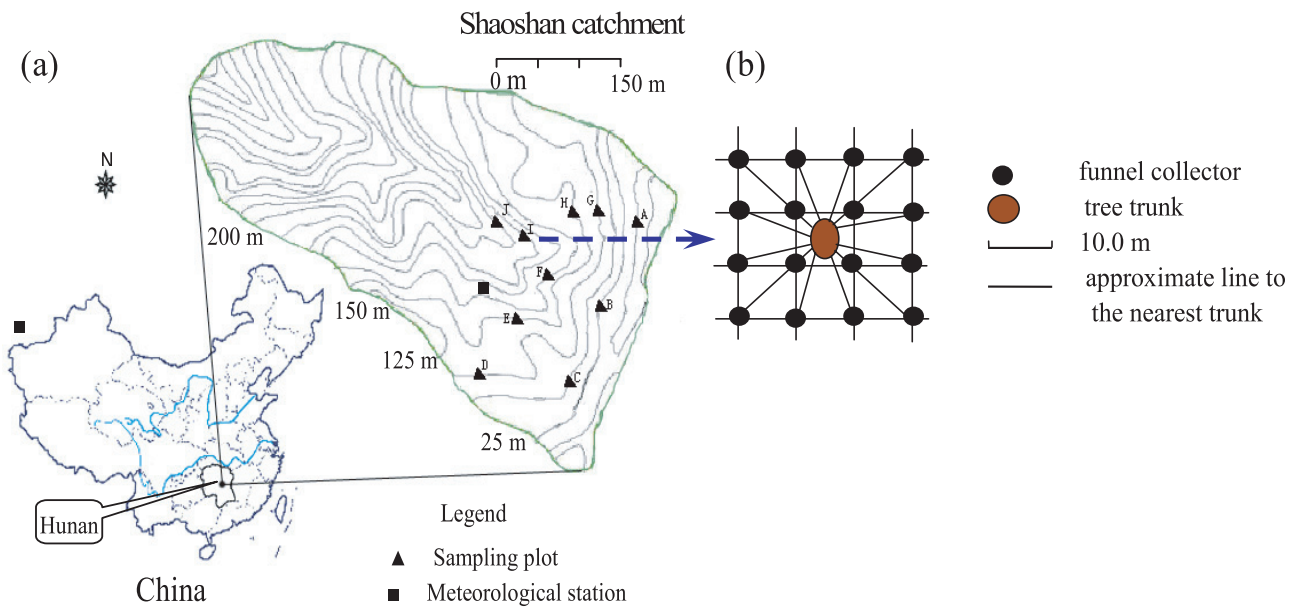

Figure 1. Location of the study site and the dispositions of plots (a), and layout of the throughfall collectors per plot (b).

subtropical monsoon climate with complex vegetation species, forest being an important resource in this province. Unfortunately, Hunan province is affected by severe acid rain pollution due to large emissions of sulfur compounds since 1980s [46]. Because of that, it is urgent to explore the mechanisms of acid rain impacting and regulating the forest ecosystems to provide local governments with effective measures to prevent damages to the forest.

This paper highlights an under-investigated feature of forest systems which is of important implications for hydrological, ecological and biogeochemical processes on the forest floor and beyond. The objectives of this study are: (i) to analyze the seasonal rainwater and acidity in the top-canopy layer and the sub-canopy layer; (ii) to calculate the canopy leaching of base cations $\left(\mathrm{Ca}^{2+}, \mathrm{Mg}^{2+}\right.$, and $\left.\mathrm{K}^{+}\right)$and the canopy exchange of nitrogen $\left(\mathrm{NO}_{3}^{-}-\mathrm{N}\right.$ and $\left.\mathrm{NH}_{4}^{+}-\mathrm{N}\right)$ and $\mathrm{H}^{+}$in the two canopy layers; and (iii) to evaluate the seasonal ionic dry deposition and total deposition in the Shaoshan subtropical forest in Central-south China.

\section{MATERIALS AND METHODS}

\subsection{Study site}

The study was conducted on the Shaoshan forested catchment (27 ha) located at the central part of Hunan Province, Central-south China ( $\left.27^{\circ} 51^{\prime} \mathrm{N}, 112^{\circ} 24^{\prime} \mathrm{E}\right)$ (Fig. 1). The site is $30 \mathrm{~km}$ away from the nearest town, Xiangtan city (with 600000 inhabitants). The obtained data were collected from ten $30 \times 30 \mathrm{~m}^{2}$ plots in the evergreen forest (25-290 m a.s.1.) from January 2000 to December 2003. Forest soil types in Shaoshan forest are yellow and yellowish-brown soils according to Chinese soil classification. The climate in this region is subtropical and monsoonal with four seasons a year. The subtropical monsoon climate of Hunan is symbolized by cold $\left(2 \sim 4{ }^{\circ} \mathrm{C}\right)$ in winter and hot $\left(30 \sim 38^{\circ} \mathrm{C}\right)$ in summer, abundant but unevenly distributed rainfall, and high relative humidity. The rainfall from June to September is almost unpolluted, but that in the other months is strongly polluted by acid rain; $35 \sim 50 \%$ of the annual rainfall is concentrated from

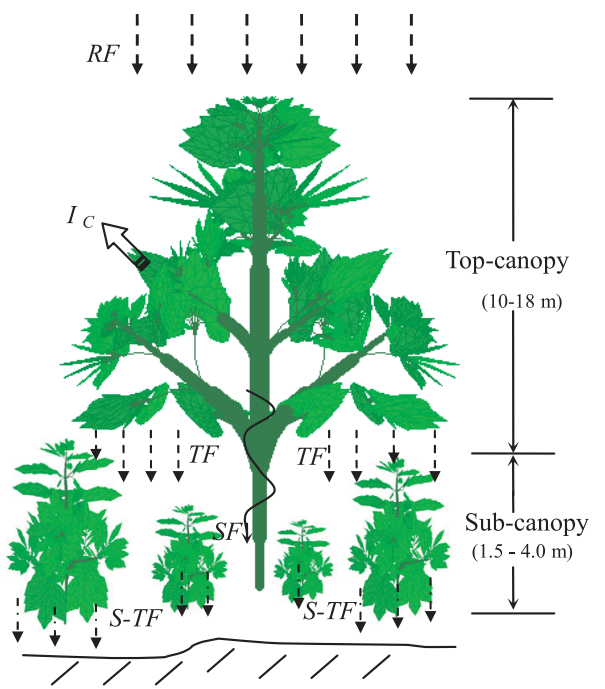

Figure 2. Schematic diagram of the two-dimension structure of the canopies and the precipitation components in the Shaoshan forest. $R F$ is the rainfall above the forest canopy; $I_{C}$ is the canopy interception; $S F$ is the stemflow; $T F$ is the throughfall of the top-canopy; $S-T F$ is the sub-throughfall of the sub-canopy.

June to August. The highest relative humidity (80 90\%) is assigned to spring and summer. Between 2000 and 2002, the annual rainfall ranged from 800 to $1900 \mathrm{~mm} \mathrm{yr}^{-1}$ and the annual average temperature varied from 17.0 to $19.0^{\circ} \mathrm{C}$ at the Shaoshan forest.

The projected top-canopy coverage of the Shaoshan stand is about $82 \%$ and that of sub-canopy is about $41 \%$. The trees' age in the forest ranges from 20 to 40 years old. The studied stand is an evergreen coniferous and deciduous mixed forest, which forms a two-layer canopy (Fig. 2). As to the top-canopy layer components, Chinese fir (Cunninghamia lanceolata) dominates the stand, and massoniana pine (Pinus Massoniana) and camphor wood (Cinnamomum camphora) are frequent species; in addition, some bamboos (Phyllostachys pubescens) grow here. Fir approximately accounts for $44 \%$, massoniana $31 \%$, camphor $20 \%$, and bamboo $5 \%$ of the total stand 
volume $\left(300 \mathrm{~m}^{3} \mathrm{ha}^{-1}\right)$. This top-canopy layer is $10 \sim 18 \mathrm{~m}$ above the sub-canopy layer. The sub-canopy is dominated by camellia (Camellia japonica), oleander (Nerium indicum), and holly (Euonumus japonicus); this sub-canopy layer is about $1.5 \sim 4.0 \mathrm{~m}$ above the forest floor.

\subsection{Sampling and laboratory analysis}

A wet-only precipitation collector from MISU (Department of Meteorology, Stockholm University, Sweden) was placed on the top of a $10 \mathrm{~m}$-high tower adjacent to throughfall plots within the studied forest. The wet deposition samples are collected daily, but the daily samples are pooled to weekly samples prior to chemical analysis. For a total of 10 plots in the Shaoshan forest, 3 plots (A-C plot) were located in the lower parts of the catchment (25-50 m a.s.1.), 5 plots (D-H plot) in the middle of the catchment (75-100 m a.s.1.) and 2 plots (I-J plot) in the upper parts (125-170 m a.s.l.). In each selected plot, 16 throughfall collectors and 12 sub-throughfall ones were installed avoiding tree trunks within each plot (Fig. 1). The throughfall collector is made of a $2 \mathrm{~L}$ plastic bottle, a plastic funnel $(\mathrm{d}=11.5 \mathrm{~cm})$, a connector with a filter (nylon screen), and mounting equipment. The collectors were opaque and kept in the dark. The throughfall and the sub-throughfall collectors were placed under the canopies and $1.0 \mathrm{~m}$ above the floor for the throughfall collector and $0.2 \mathrm{~m}$ for sub-throughfall, respectively. The fiber plugs were replaced by new ones and each collector was rinsed three times using distilled water $(100 \mathrm{~mL})$ after weekly collection. $\mathrm{CHCl}_{3}$ was added as a preservative to prevent biological activity. The 16 throughfall samples and the 12 sub-throughfall ones in each plot were pooled into two different containers, respectively. The weekly samples were mixed in the lab to obtain monthly samples for chemical analysis.

All collected samples were kept at $4{ }^{\circ} \mathrm{C}$ and transported to laboratory for chemical analysis. $\mathrm{SO}_{4}^{2-}, \mathrm{NO}_{3}^{-}, \mathrm{Cl}^{-}, \mathrm{Na}^{+}$, and $\mathrm{NH}_{4}^{+}$were determined by ion chromatography (IC) (Dionex 320 system, USA). $\mathrm{Ca}^{2+}, \mathrm{Mg}^{2+}$, and $\mathrm{K}^{+}$were determined by flame atomic absorption spectroscopy (FAAS) (SH-3800, Japan) in laboratory, while the conductivity was measured by electrometer and $\mathrm{pH}$ by potentiometer in unfiltered solutions at $25^{\circ} \mathrm{C}$.

\subsection{Calculation of total deposition and canopy leaching of basic cations}

Total deposition (TD) was calculated according to a slightly adapted canopy budget model developed by Ulrich [41] and extended by Bredemeier [4], Draaijers and Erisman [10] and Zeng et al. [46]. In the canopy budget model, annual total deposition is derived by correcting the input with both throughfall (TF) and stemflow (SF) for exchange processes occurring within the forest canopies [13]. In our present study, stemflow flux was assumed to be zero because the volume of stemflow in our study did not arrive at the standard volume to determine.

Canopy leaching induced by the internal cycle of these nutrients was thus computed by the difference between the sum of base cations (BC) $\left(\mathrm{Ca}^{2+}, \mathrm{Mg}^{2+}\right.$, and $\left.\mathrm{K}^{+}\right)$in throughfall and stemflow minus total deposition in each canopy according to:

$$
C L_{B C}=T F_{B C}+S F_{B C}-T D_{B C}
$$

$C L_{B C}$ is the canopy leaching of base cations (meq $\mathrm{m}^{-2}$ season $^{-1}$ ),

$T F_{B C}$ the throughfall flux of base cations (meq $\mathrm{m}^{-2}$ season $^{-1}$ ),

$S F_{B C}$ the stemflow flux of base cations (meq $\mathrm{m}^{-2}$ season $^{-1}$ ),

$T D_{B C}$ the total deposition flux of basic cations (meq $\mathrm{m}^{-2}$ season $^{-1}$ ).

$T D_{B C}$ were calculated according to Reynolds [38]. These calculations are based on the assumption that: (i) $\mathrm{Na}$ does not interact with the forest canopy (inert tracer); and (ii) the ratios of total deposition over bulk deposition are similar for $\mathrm{Ca}, \mathrm{Mg}, \mathrm{K}$, and $\mathrm{Na}$.

$$
T D_{B C}=D D_{B C}+P D_{B C}
$$

where, $D D_{B C}$ is the dry deposition of base cations (meq $\mathrm{m}^{-2}$ season $^{-1}$ ) and $P D_{B C}$ the deposition by precipitation (meq $\mathrm{m}^{-2}$ season $^{-1}$ ).

And $D D_{B C}$ is calculated according to:

$$
D D_{B C}=\frac{T F_{N a}+S F_{N a}}{P D_{N a}} \cdot P D_{B C}-P D_{B C}
$$

where, $T F_{N a}, S F_{N a}$, and $P D_{N a}$ are the flux of $\mathrm{Na}$ in the throughfall, the stemflow, and the precipitation deposition, respectively.

\subsection{Calculations of total deposition and canopy exchange}

Total canopy uptake of $\mathrm{H}^{+}$and $\mathrm{NH}_{4}^{+}$was assumed to be equal to the total canopy leaching of $\mathrm{Ca}^{2+}, \mathrm{Mg}^{2+}$, and $\mathrm{K}^{+}$corrected for the exchange of weak acids $[10,46]$. The throughfall flux of $\mathrm{NH}_{4}^{+}$was thus corrected for canopy uptake to calculate the total deposition of $\mathrm{NH}_{4}^{+}$according to Erisman et al. [16] and Zhang et al. [47].

Canopy exchange of $\mathrm{N}$ in each canopy was calculated according to:

$$
C E_{N}=C E_{N H_{4}^{+}} \cdot\left(\frac{T F_{N H_{4}^{+}} \cdot X_{N H_{4}^{+}}+T F_{N O_{3}^{-}}}{T F_{N H_{4}^{+}} \cdot X_{N H_{4}^{+}}}\right)
$$

where, $\mathrm{CE}_{\mathrm{NH}_{4}^{+}}$is:

$$
C E_{N H_{4}^{+}}=C L_{B C}-C E_{H^{+}} .
$$

And $C E_{H^{+}}$is:

$$
C E_{H^{+}}=C L_{B C} /\left(1+\left(1 /\left[6 \times\left(T F_{H^{+}} / T F_{N H_{4}^{+}}+P D_{H^{+}} / P D_{N H_{4}^{+}}\right) / 2\right]\right)\right)
$$

$X_{N H 4}$ is an efficiency factor of $\mathrm{NH}_{4}^{+}$in comparison to $\mathrm{NO}_{3}^{-}$, which was assumed that $\mathrm{X}_{\mathrm{NH} 4}$ is equal to 6 [16]. Actually, there is a controversy over the negligible canopy uptake of $\mathrm{NO}_{3}^{-}$. Up to now, several basic assumptions in the model (e.g. the ratio in exchange efficiency between $\mathrm{H}^{+}$and $\mathrm{NH}_{4}^{+}$) are not properly evaluated for different environmental conditions (tree species, ecological setting and pollution climate) which limit its application [10].

The total depositions of $\mathrm{NH}_{4}^{+}, \mathrm{H}^{+}$, and $\mathrm{NO}_{3}^{-}$were calculated according to:

$$
T D_{X_{i}}=T F_{X_{i}}+S F_{X_{i}}+C E_{X_{i}}
$$

where $\mathrm{X}_{i}$ stands for a given ion $\left(\mathrm{NH}_{4}^{+}, \mathrm{H}^{+}\right.$, and $\left.\mathrm{NO}_{3}^{-}\right)$in the subcanopy layer. Canopy exchange of $\mathrm{NO}_{3}^{-}$equals the canopy exchange of nitrogen minus the exchange of $\mathrm{NH}_{4}^{+}$.

Although the leaching evidences of $\mathrm{SO}_{4}^{2-}$ have been reported in eastern Finland forests and $\mathrm{SO}_{4}^{2-}$ will accelerate base cations leach from canopy [34], canopy exchange of $\mathrm{SO}_{4}^{2-}$ and $\mathrm{Cl}^{-}$were assumed to be negligible in our study, as in other forests $[4,10,25]$. Thus, the total depositions of the two ions were calculated according to:

$$
T D_{X_{i}}=T F_{X_{i}}+S F_{X_{i}} .
$$

where, 
Table I. Physico-chemical properties of soils in Shaoshan forest.

\begin{tabular}{|c|c|c|c|c|c|c|c|c|c|c|}
\hline Horizon & $\begin{array}{l}\text { Depth } \\
(\mathrm{cm})\end{array}$ & $\mathrm{pH}\left(\mathrm{H}_{2} \mathrm{O}\right)$ & $\begin{array}{c}\mathrm{CEC}^{\mathrm{a}} \\
\left(\mathrm{cmol} \mathrm{kg}^{-1}\right)\end{array}$ & $\begin{array}{l}\mathrm{BS}^{\mathrm{b}} \\
(\%)\end{array}$ & $\begin{array}{c}\mathrm{SOC}^{\mathrm{c}} \\
\left(\mathrm{g} \mathrm{C} \mathrm{kg}^{-1}\right)\end{array}$ & $\begin{array}{l}\text { Total N } \\
\left(\mathrm{g} \mathrm{kg}^{-1}\right)\end{array}$ & $\mathrm{C} / \mathrm{N}$ & $\begin{array}{c}\mathrm{Ca}^{2+} \\
\left(1 / 2 \mathrm{cmol}_{\mathrm{c}} \mathrm{kg}^{-1}\right)\end{array}$ & $\begin{array}{c}\mathrm{Mg}^{2+} \\
\left(1 / 2 \mathrm{cmol}_{\mathrm{c}} \mathrm{kg}^{-1}\right)\end{array}$ & $\begin{array}{c}\mathrm{K}^{+} \\
\left(\mathrm{cmol}_{\mathrm{c}} \mathrm{kg}^{-1}\right)\end{array}$ \\
\hline $\mathrm{O} / \mathrm{A}$ & $0-20$ & $4.96 \pm 0.05$ & $17 \pm 2.1$ & $27 \pm 5.3$ & $31 \pm 2.1$ & $1.52 \pm 0.07$ & $20.1 \pm 2.3$ & $8.6 \pm 1.27$ & $0.09 \pm 0.07$ & $0.68 \pm 2.63$ \\
\hline B & $20-40$ & $4.73 \pm 0.03$ & $15 \pm 1.8$ & $19 \pm 3.7$ & $20 \pm 1.7$ & $1.12 \pm 0.04$ & $18.3 \pm 1.4$ & $3.2 \pm 0.84$ & $0.10 \pm 0.09$ & $0.46 \pm 1.27$ \\
\hline
\end{tabular}

${ }^{\mathrm{a}}$ Cation exchange capacity; ${ }^{\mathrm{b}}$ percentage of base saturation; ${ }^{\mathrm{c}}$ soil organic carbon.

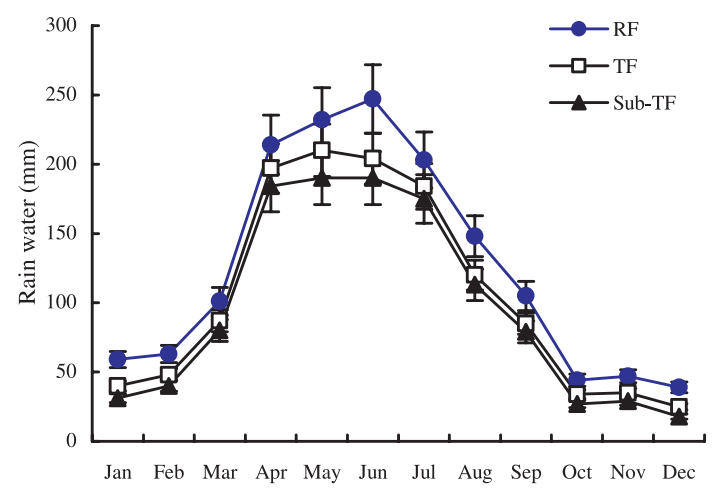

Figure 3. Monthly volumes of rainwater in rainfall (RF), throughfall (TF), and sub-throughfall (Sub-TF).

\subsection{Flux calculations and statistical analysis}

The fluxes of throughfall, sub-throughfall, and bulk precipitation were calculated by multiplying the volume-weighted concentration by the amount of water and by making the necessary conversions to express the flux in meq $\mathrm{m}^{-2}$ season $^{-1}$.

Statistical differences in rainwater quantity, ion concentrations, and fluxes in the bulk precipitation and throughfall were examined by using one-way analysis of variance (SPSS 10.0 for Windows).

\section{RESULTS}

\subsection{Soil characteristics}

As shown in Table I, $\mathrm{pH}\left(\mathrm{H}_{2} \mathrm{O}\right)$ of the top soils $(\mathrm{O} / \mathrm{A}$ horizon, $0-20 \mathrm{~cm}$ ) was slightly higher that that in lower ones (B horizon, 20-40 cm), and soil organic carbon (SOC), total nitrogen $(\mathrm{N})$, and cation exchange capacity (CEC) were accumulated much more in the top soils than in $\mathrm{B}$ horizons in the same soil profile. The contents of $\mathrm{Ca}^{2+}$ and $\mathrm{K}^{+}$in the top soils were much higher than in $\mathrm{B}$ horizons. Whereas, the content of $\mathrm{Mg}^{2+}$ in $\mathrm{O} / \mathrm{A}$ horizons was lower than in $\mathrm{B}$ horizons. It is noted that the contents of $\mathrm{Mg}^{2+}$ are much lower than $\mathrm{Ca}^{2+}$ and $\mathrm{K}^{+}$in both the two horizons.

\subsection{Precipitation and canopy interception losses}

The annual water amount covered as bulk precipitation, throughfall, and sub-throughfall was 1401, 1191, and

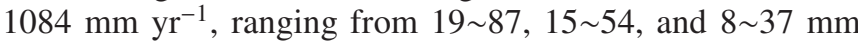

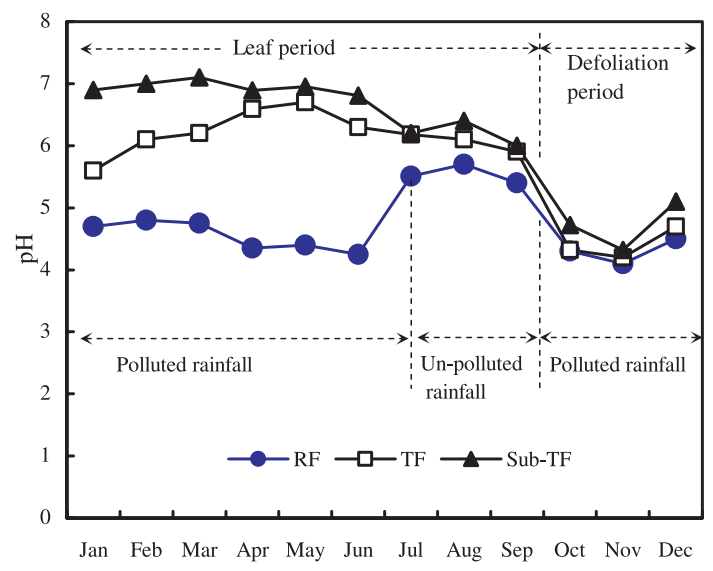

Figure 4. $\mathrm{pH}$ value in rainfall (RF), throughfall (TF) and subthroughfall (Sub-TF) during the year of 2002.

week $^{-1}$, respectively. However, rainfall in 2000 (wet) and 2001 (dry) were significantly deviated from annual mean values of 1200-1500 mm in the last decade, with $1900 \mathrm{~mm}$ in 2000 and $800 \mathrm{~mm}$ in 2001, respectively, which may resulted from the series of storms in 2000 and the long dry period in 2001. In contrast, the rain quantity of $1503 \mathrm{~mm}$ in 2002 was in good agreement with the annual mean values. Rainfall in spring plus summer (rainfall period ranging from March to July) accounted for $76 \%$ of the annual averaged quantity (Fig. 3). About 210 and $107 \mathrm{~mm} \mathrm{yr}^{-1}$ of the rainfall was intercepted by the top- and sub-canopy, indicating that $15 \%$ of annual precipitation was intercepted by the top-canopy, and $9 \%$ of throughfall (or $8 \%$ of the bulk precipitation) was retained by the subcanopy.

\section{3. $\mathrm{pH}$ of rainfall, throughfall, and sub-throughfall}

As discussed earlier, the rainfall amount and the meteorological conditions registered in 2002 are more representative than those during 2000 and 2001. Rainwater $\mathrm{pH}$ varied monthly from 4.1 to 5.7 in precipitation, 4.2 to 6.7 in throughfall, and 4.3 to 7.1 in sub-throughfall during 2002 (Fig. 4). Seasonal mean-pH value were $4.7,4.3,5.5$, and 4.3 in rainwater, 6.0, 6.6, 6.2, and 4.3 in throughfall and 7.0, 6.9, 6.1, and 4.7 in sub-throughfall in spring, summer, autumn, and winter, respectively. 
Table II. $\mathrm{pH}$ value and the volume-weighted concentration of ions $\left(\mu \mathrm{eq} \mathrm{L}^{-1}\right)$ in the bulk precipitation (BP), throughfall (TF), and sub-throughfall (STF) in Shaoshan forest during the studied period (2000-2002). Standard errors are given in parenthesis.

\begin{tabular}{|c|c|c|c|c|c|c|c|c|c|c|}
\hline & & $\mathrm{pH}$ & $\mathrm{Ca}^{2+}$ & $\mathrm{Mg}^{2+}$ & $\mathrm{K}^{+}$ & $\mathrm{Na}^{+}$ & $\mathrm{NH}_{4}^{+}$ & $\mathrm{SO}_{4}^{2-}$ & $\mathrm{NO}_{3}^{-}$ & $\mathrm{Cl}^{-}$ \\
\hline \multirow[t]{2}{*}{ Spring } & $B P$ & 4.7 & $32.5^{* *}$ & $9.4^{*}$ & $13.5^{* *}$ & $12.2^{* *}$ & $215.6^{* * *}$ & $31.9^{* *}$ & $24.0^{*}$ & $17.8^{* *}$ \\
\hline & & $(0.2)$ & $(4.2)$ & (1.3) & (3.6) & $(3.1)$ & (18.4) & $(5.2)$ & (3.1) & (2.4) \\
\hline \multirow[t]{4}{*}{ (Mar. May) } & $T F$ & 6.0 & $237.5^{*}$ & $24.7^{*}$ & $79.8^{*}$ & $21.3^{* *}$ & $311.5^{* *}$ & $64.4^{* *}$ & $20.2^{*}$ & $59.2^{* *}$ \\
\hline & & $(0.3)$ & (20.4) & (3.1) & $(8.5)$ & $(3.1)$ & (19.9) & (6.6) & $(4.2)$ & $(6.2)$ \\
\hline & $S T F$ & 7.0 & $285.0^{*}$ & $28.8^{*}$ & $51.1^{* *}$ & $31.7^{* *}$ & $121.9^{*}$ & $66.7^{* *}$ & $37.7^{*}$ & $20.5^{*}$ \\
\hline & & $(0.3)$ & (16.4) & (3.9) & $(6.9)$ & $(4.6)$ & (12.3) & $(5.9)$ & (5.1) & (4.6) \\
\hline \multirow[t]{2}{*}{ Summer } & $B P$ & 4.3 & $85.0^{* *}$ & $18.5^{* *}$ & $7.4^{*}$ & $15.7^{*}$ & $66.5^{* *}$ & $24.9^{*}$ & $1.6^{*}$ & $57.3^{*}$ \\
\hline & & $(0.1)$ & $(5.6)$ & $(2.1)$ & $(0.5)$ & (2.0) & (4.7) & (3.7) & $(0.3)$ & (6.2) \\
\hline \multirow[t]{4}{*}{ (Jun. $\sim$ Aug.) } & $T F$ & 6.5 & $166.0^{*}$ & $32.9^{* *}$ & $80.8^{* *}$ & $22.2^{* *}$ & $190.1^{* *}$ & $45.7^{*}$ & $11.5^{*}$ & $80.1^{* *}$ \\
\hline & & $(0.3)$ & (11.2) & (3.6) & $(8.7)$ & $(3.0)$ & $(18.1)$ & (6.4) & (1.3) & $(7.1)$ \\
\hline & $S T F$ & 6.9 & $242.5^{* *}$ & $4.1^{* *}$ & $99.8^{* *}$ & $34.3^{* *}$ & $100.3^{* *}$ & $50.4^{*}$ & $25.0^{* *}$ & $66.3^{*}$ \\
\hline & & $(0.2)$ & (11.8) & $(0.7)$ & (6.4) & $(4.6)$ & $(10.2)$ & (7.0) & $(2.5)$ & (6.8) \\
\hline \multirow[t]{2}{*}{ Autumn } & $B P$ & 5.5 & $25.3^{* *}$ & $7.4^{* * *}$ & $5.6^{*}$ & $7.0^{*}$ & $30.5^{* *}$ & $25.1^{*}$ & $6.9^{*}$ & $6.8^{*}$ \\
\hline & & $(0.2)$ & (3.7) & (1.3) & $(0.5)$ & $(0.8)$ & $(5.0)$ & (4.1) & $(0.6)$ & (1.3) \\
\hline \multirow[t]{4}{*}{ (Sep. $\sim$ Nov.) } & $T F$ & 6.2 & $122.5^{* *}$ & $31.2^{* *}$ & $122.8^{* * *}$ & $14.8^{*}$ & $173.5^{* *}$ & $48.7^{*}$ & $27.7^{*}$ & $61.5^{*}$ \\
\hline & & $(0.3)$ & $(9.4)$ & $(4.0)$ & (11.4) & (2.3) & $(8.3)$ & (4.9) & (4.1) & (6.1) \\
\hline & $S T F$ & 6.1 & $138.0^{* *}$ & $53.0^{* *}$ & $192.8^{* *}$ & $33.0^{*}$ & $284.4^{* *}$ & $63.4^{*}$ & $39.5^{*}$ & $133.7^{*}$ \\
\hline & & $(0.3)$ & $(10.8)$ & $(5.8)$ & $(16.3)$ & (4.7) & $(16.7)$ & (6.7) & (3.8) & $(9.5)$ \\
\hline \multirow[t]{2}{*}{ Winter } & $B P$ & 4.3 & $22.5^{* *}$ & $4.1^{* *}$ & $12.8^{*}$ & $13.0^{* *}$ & $105.3^{* *}$ & $29.1^{*}$ & $12.9^{*}$ & $16.9^{*}$ \\
\hline & & $(0.2)$ & $(4.5)$ & $(0.4)$ & (2.3) & $(2.6)$ & $(9.9)$ & (4.6) & (2.0) & (2.9) \\
\hline \multirow[t]{4}{*}{ (Dec. F Feb.) } & $T F$ & 4.3 & $177.5^{* *}$ & $53.4^{* *}$ & $150.9^{* *}$ & $25.6^{*}$ & $133.0^{*}$ & $99.7^{*}$ & $35.5^{*}$ & $138.2^{* *}$ \\
\hline & & $(0.1)$ & $(10.5)$ & $(6.2)$ & $(8.4)$ & $(3.2)$ & $(11.3)$ & $(8.8)$ & $(3.5)$ & (10.8) \\
\hline & $S T F$ & 4.7 & $227.5^{*}$ & $74.5^{*}$ & $120.2^{* *}$ & $26.1^{*}$ & $138.6^{* *}$ & $134.4^{*}$ & $40.3^{*}$ & $132.6^{* * *}$ \\
\hline & & $(0.2)$ & $(15.3)$ & (8.4) & $(13.1)$ & $(4.0)$ & $(14.0)$ & (13.4) & (6.4) & (11.3) \\
\hline \multirow[t]{6}{*}{ Annual mean } & $B P$ & 4.7 & $41.3^{*}$ & $9.9^{*}$ & $9.8^{*}$ & $12.0^{*}$ & $104.5^{* *}$ & $27.8^{*}$ & $11.4^{*}$ & $24.7^{*}$ \\
\hline & & $(0.1)$ & (3.7) & (1.2) & (1.0) & (1.4) & $(9.9)$ & (3.4) & (2.3) & (3.8) \\
\hline & $T F$ & 5.8 & $175.9^{*}$ & $35.6^{*}$ & $108.6^{* *}$ & $21.0^{*}$ & $202.0^{* *}$ & $64.6^{*}$ & $23.7^{*}$ & $84.8^{* *}$ \\
\hline & & $(0.3)$ & $(10.2)$ & (3.4) & $(9.1)$ & (3.1) & $(13.7)$ & (6.4) & (3.4) & (5.1) \\
\hline & $S T F$ & 6.2 & $223.3^{* *}$ & $40.1^{*}$ & $116.0^{* *}$ & $31.3^{* *}$ & $161.3^{* *}$ & $78.7^{*}$ & 35.6 & $88.3^{* *}$ \\
\hline & & $(0.5)$ & (12.3) & (5.4) & $(8.7)$ & $(4.2)$ & $(8.8)$ & (6.1) & (3.5) & (4.9) \\
\hline
\end{tabular}

${ }^{*} P<0.05 ;{ }^{* *} P<0.01 ;{ }^{* * *} P<0.001$.

\subsection{Seasonal canopy leaching of basic cations}

The volume weighted concentrations of ions in bulk precipitation, throughfall, and sub-throughfall were presented in Table II. The concentrations in throughfall and sub- throughfall were increased referred to the bulk precipitation, but the increased extents in throughfall were significantly higher than in the sub-throughfall (Fig. 5).

The leaching of $\mathrm{Ca}^{2+}$ in the top-canopy in spring and winter was the highest in the leaching of basic cations, with a leaching flux of 40.1 and $29.4 \mathrm{meq} \mathrm{m}^{-2}$, respectively. But the highest leaching in the other two seasons was $\mathrm{K}^{+}$, with a flux of $52.1 \mathrm{meq} \mathrm{m}^{-2}$ in summer and $49.0 \mathrm{meq} \mathrm{m}^{-2}$ in autumn (Fig. 5).

The highest sub-canopy leaching in spring and autumn was registered by $\mathrm{K}^{+}$. However, the highest one in summer and winter was registered by $\mathrm{Ca}^{2+}$ (Fig. 5). Annual averaged sub- canopy leaching of $\mathrm{Ca}^{2+}, \mathrm{Mg}^{2+}$, and $\mathrm{K}^{+}$accounted for 47.3 , 0.02 , and $52.6 \%$ of increases referred to throughfall, respectively.

It is noted that the leaching of $\mathrm{Mg}^{2+}$ in the sub-canopy both in spring $\left(-0.6\right.$ meq m$^{-2}$ season $\left.^{-1}\right)$ and summer $\left(-1.2\right.$ meq $^{-2}$ season $^{-1}$ ) was negative (Fig. 5), which indicated the leaf adsorption in this canopy layer during the two seasons.

\subsection{Seasonal canopy exchange of $\mathrm{H}^{+}$and nitrogen}

The highest uptake of $\mathrm{H}^{+}$in the top-canopy was in summer with $77.8 \mathrm{meq} \mathrm{m}^{-2}$, followed by $71.6 \mathrm{meq} \mathrm{m}^{-2}$ in autumn. Similarly, the highest uptake $\mathrm{H}^{+}$in the sub-canopy was in summer, followed by autumn. The canopy uptake of $\mathrm{H}^{+}$both in the 

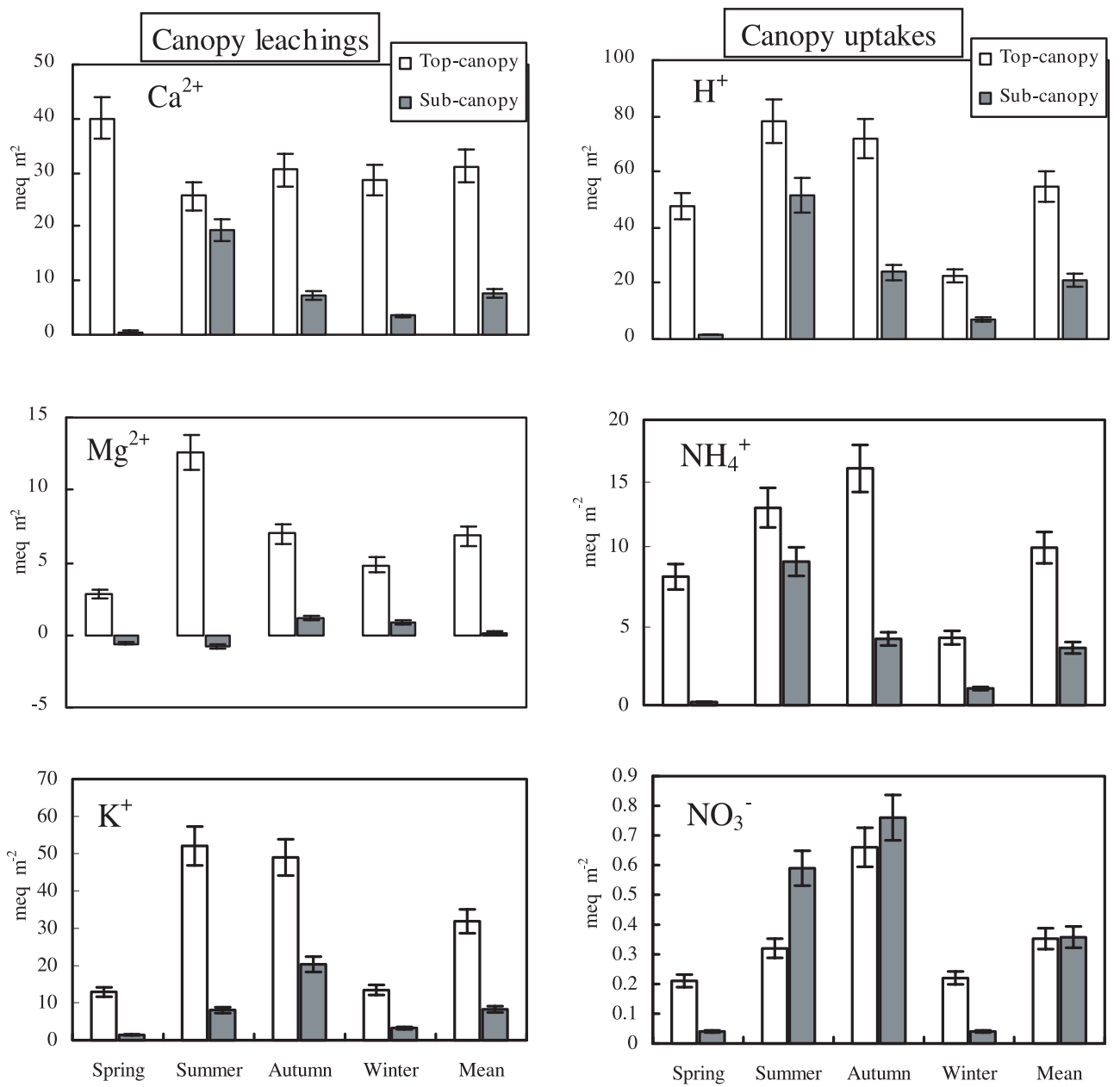

Figure 5. Seasonal canopy leaching and uptake of ions in the top-canopy and sub-canopy in the Shaoshan forest during 2000-2002.

top-canopy and sub-canopy layer was higher than the uptake of $\mathrm{NH}_{4}^{+}$in the two canopies (Fig. 5).

In spring, the canopy uptake rate of $\mathrm{NH}_{4}^{+}$was $8.1 \mathrm{meq} \mathrm{m}^{-2}$ and that of $\mathrm{NO}_{3}^{-}$was $0.2 \mathrm{meq} \mathrm{m}^{-2}$, indicating the uptake rate of $\mathrm{NH}_{4}^{+}$was about 39 times higher than that of $\mathrm{NO}_{3}^{-}$. Furthermore, the ratio of $\mathrm{NH}_{4}^{+} / \mathrm{NO}_{3}^{-}$in the top-canopy was 39,23 , and 19 in summer, autumn, and winter, respectively.

Canopy uptake rate of $\mathrm{NH}_{4}^{+}$in the sub-canopy was significantly lower than that in canopy layer in the four seasons, whereas, the uptake of $\mathrm{NO}_{3}^{-}$in sub-canopy was higher than that in the top-canopy in summer and autumn (Fig. 5). The ratio of $\mathrm{NH}_{4}^{+} / \mathrm{NO}_{3}^{-}$in sub-canopy layer was low relative to canopy layer. Furthermore, the increment of $\mathrm{NO}_{3}^{-}$ concentration in throughfall and sub-throughfall were higher than that of $\mathrm{NH}_{4}^{+}$(Tab. II).

\subsection{Seasonal ionic total deposition (TD) and dry deposition (DD)}

The estimated seasonal total base cations depositions $\left(T D_{B C}\right)$ were $73.1,66.3,75.3$, and $6.4 \mathrm{meq}^{-2}$ in spring, summer, autumn, and winter, respectively (Fig. 6). Seasonal total deposition of $\mathrm{Ca}^{2+}$ accounted for the $90,77,66$, and $52 \%$ of $T D_{B C}$ in spring, summer, autumn, and winter, with an annual mean of $77 \%$, respectively. The calculated seasonal $T D$ of $\mathrm{K}^{+}$ amounted to the $5.7,6.6,14.7$, and $29.4 \%$ of seasonal $T D_{B C}$ in spring, summer, autumn and winter, respectively. Seasonal $T D$ of $\mathrm{Mg}^{2+}$ had the lowest percentage referred to $T D_{B C}$ in all seasons, except autumn (Fig. 6). The highest seasonal $T D_{C l^{-}}$was in summer with $17.1 \mathrm{meq} \mathrm{m}^{-2}$ and that in autumn was to the next by $14.1 \mathrm{meq} \mathrm{m}^{-2}$.

The averaged seasonal $T D$ of $\mathrm{NH}_{4}^{+}$was 87.0, 55.5, 56.3, and $8.6 \mathrm{meq} \mathrm{m}^{-2}$ in spring, summer, autumn, and winter, respectively (Fig. 6). Annual mean $T D_{N}\left(\mathrm{NH}_{4}^{+}-\mathrm{N}, \mathrm{NO}_{3}^{-}-\mathrm{N}\right)$ was $221.8 \mathrm{meq} \mathrm{m}^{-2} \mathrm{yr}^{-1}$, accounting for $26.5 \%$ of annual ions $T D$.

The estimated annual dry deposition of $\mathrm{NH}_{4}^{+}\left(D D_{N H_{4}^{+}}\right)$was $\sim 30.6 \%$ of annual $T D_{N_{4}^{+}}$. $D D_{N_{3}^{-}}$was about $17.6 \%$ of annual $T D_{\mathrm{NO}_{3}^{-}}$. Annual mean $D D_{\mathrm{Ca}^{2+}}, D^{3} D_{\mathrm{Mg}^{2+}}$ and $D D_{\mathrm{K}^{+}}$were approximate to $53.1,28.2$, and $29.8 \%$ of annual $T D_{\mathrm{Ca}^{2+}}, T D_{M q^{2+}}$ and $T D_{K^{+}}$, respectively. Seasonal $D D_{B C}$ accounted for 53.0, $12.7,36.9$, and $64.8 \%$ of seasonal $T D_{B C}$ in spring, summer, autumn, and winter, respectively. Seasonal percentage of $D D_{\mathrm{SO}_{4}^{2-}}$ in annual $\mathrm{DD}_{\mathrm{SO}_{4}^{2-}}$ was $63.8 \%$ in spring, $23.2 \%$ in summer, $38.5 \%$ in autumn, and $60.6 \%$ in winter. 

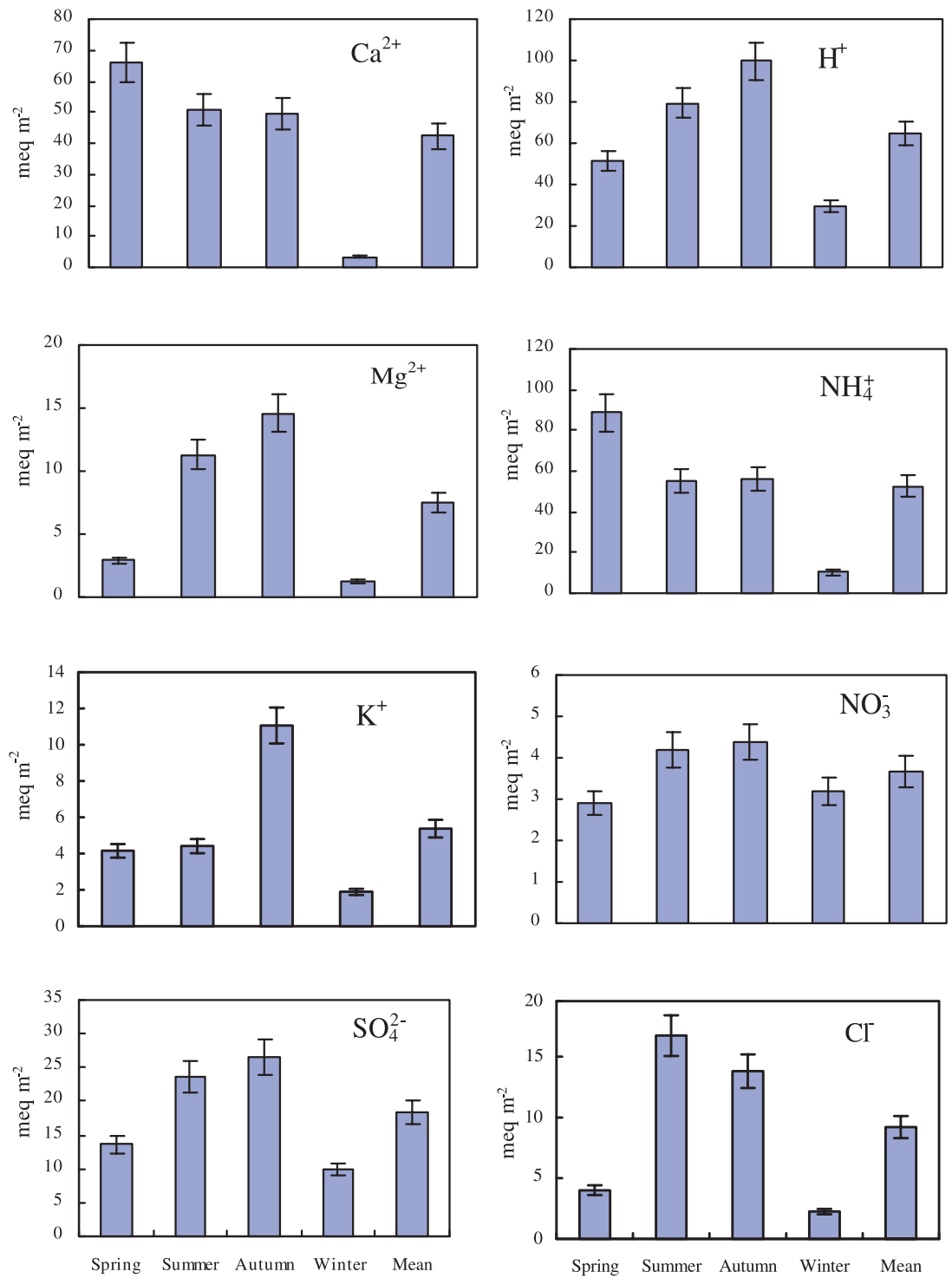

Figure 6. Seasonal ionic total deposition $(T D)\left(\mathrm{meq} \mathrm{m}^{-2}\right)$ in the Shaoshan forest during the period of 2000-2002.

\section{DISCUSSION}

\subsection{Rainwater quantity in throughfall and sub-throughfall}

Most of the rainfall in the Shaoshan forest is concentrated over the rainy period from April to July, accounting for $>70 \%$ of annual precipitation. The unevenly distributed rainfall in Hunan region is mainly attributed to the influence of subtropical monsoon climate. Taiwan rainforest has the similar unevenly distributed rain quantity, but the rainfall is influenced by typhoon [24]. Fifteen per cent of precipitation was intercepted by the top-canopy and $8 \%$ of precipitation (or $9 \%$ of the throughfall) was retained by the sub-canopy. As shown in Figure 3, water fluxes from the top-canopy to forest floor decreased gradually, the smaller the flux of water is, the longer the contact of water on leaf surface takes place [20]. So, an ac- tive exchange process in the lower parts of the canopy seems to be possible.

The canopy interception $\left(I_{c}\right)$ in Shaoshan forest showed the positively linear relationship with rainfall $\left(R^{2}=0.89\right.$ for the top-canopy, $P<0.05)$ and $\left(R^{2}=0.88\right.$ for the sub-canopy, $P<$ 0.01 ) during the studied period (Fig. 7). A similar relationship between the rainfall and the canopy interception loss $\left(I_{c}\right)$ has been reported in the forest in southeast Asia [40] and in the Amazonian terra-firma rain-forest [7].

\section{2. $\mathrm{pH}$ of the bulk precipitation, throughfall and sub-throughfall waters}

Monthly mean $\mathrm{pH}$ values in the sub-throughfall were generally higher than the throughfall and bulk precipitation (Fig. 4). The increased extent of $\mathrm{pH}$ value was significantly different in 


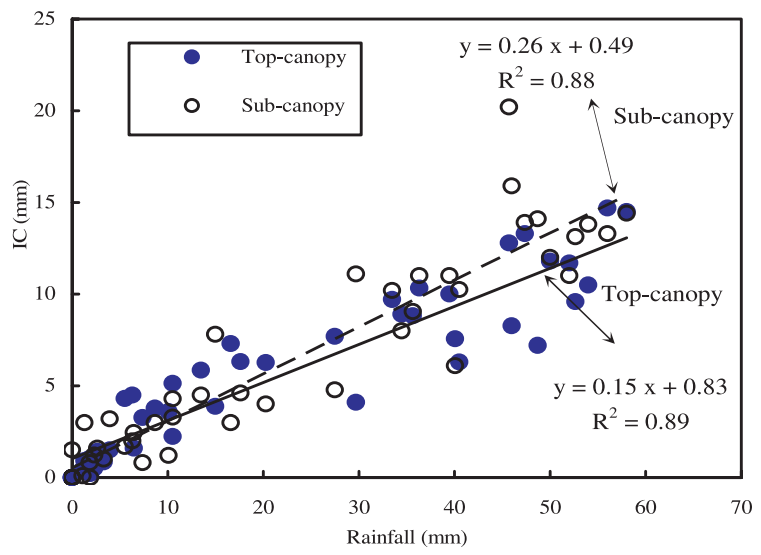

Figure 7. Relationship between rainfall and canopy interception $\left(I_{C}\right)$ in canopy during the studied period.

different canopy layers and different seasons. The largest increased $\mathrm{pH}$ occurred in summer with a net increase of $2.3 \mathrm{pH}$ units in canopy (from 4.3 to 6.6) referred to that in the bulk precipitation (4.3), followed by spring, (Fig. 4 and Tab. I), which indicated that the severe acidity was highly neutralized through the canopy exchange process. $\mathrm{pH}$ value of rainwater in winter was below 5.6, which corresponded to the long dry months which may facilitate the accumulation of acid substance in the atmosphere and pollute the rainwater. Little canopy exchange process was observed in this period because of the defoliation of trees in the Shaoshan forest.

\subsection{Leaching of base cations from the top- and sub-canopy layers}

In the top-canopy layer, the highest leaching of $\mathrm{Ca}^{2+}$ was in spring and that of $\mathrm{K}^{+}$and $\mathrm{Mg}^{2+}$ both occurred in summer. Zeng et al. [46] found that acid rainwater strongly leached the plant nutrients, especially basic cations, when $\mathrm{pH}$ of rainwater was about 4.5. The seasonal $\mathrm{pH}$ of rainwater in summer (4.3) and winter (4.3) was very low, being a little bit higher in spring (4.7). As said, rain quantity in spring and summer accounted for more than $70 \%$ of annual rainfall. Furthermore, tree species grow during spring and summer in the Shaoshan forest. In that situation, canopy exchange (leaching and uptake) processes will take place when the acid rain crosses through the canopy layer. Hansen [20] observed a higher leaching of $\mathrm{K}^{+}$from the canopy driven by the large amount of acid rainwater in Norway spruce and Lovett et al. [27] modeled a higher leaching in the canopy in a balsam fir canopy during the growth times.

The canopy leaching of $\mathrm{Ca}^{2+}, \mathrm{Mg}^{2+}$, and $\mathrm{K}^{+}$in the subcanopy was much lower than that in the top-canopy (Fig. 5). As shown in Table II and Figure 4, seasonal $\mathrm{pH}$ value in throughfall was increased to higher than 5.6, except in winter, which reduced the leaching capacity because $\mathrm{H}^{+}$in rainwater has been highly consumed through exchange with basic cations in the top-canopy layer. The throughfall with the enriched base cations will continually go down to the lower canopy parts, but the rain amount will be decreased by interception loss or evaporation. As discussed earlier, the low amount of rainwater will prolong the contact of water on leaf surfaces, which may facilitate the exchange of nutrients between water solution and leaf surfaces in the sub-canopy. As shown in Table I, the soil in the Shaoshan forest is deficient of $\mathrm{Mg}$, but has enough $\mathrm{Ca}^{2+}$ and $\mathrm{K}^{+}$. Increased acidity caused increased foliar leaching of base cations, mainly $\mathrm{Ca}^{2+}$ and $\mathrm{K}^{+}$. The canopy leaves tend to absorb $\mathrm{Mg}^{2+}$ from water solution to compensate the soil deficiency, which is coherent with the negative leaching of $\mathrm{Mg}^{2+}$ in spring and summer (Fig. 5).

\subsection{Uptake of nitrogen $\left(\mathrm{NH}_{4}^{+}-\mathrm{N}, \mathrm{NO}_{3}^{-}-\mathrm{N}\right)$ and $\mathrm{H}^{+}$ in the two canopy layers}

The canopy uptake of $\mathrm{NO}_{3}^{-}$in the two canopy layers was negligible compared with that of $\mathrm{NH}_{4}^{+}$(Fig. 6). Although canopy uptake of $\mathrm{NO}_{3}^{-}$was observed during the dripping process, $\mathrm{NH}_{4}^{+}$was more easily absorbed by canopy than $\mathrm{NO}_{3}^{-}[19$, 35]. Many studies have confirmed a preferential and higher uptake of $\mathrm{NH}_{4}^{+}$than that of $\mathrm{NO}_{3}^{-}$in Norway spruce trees, Fujian plantations, and Taiwan rainforest $[15,18,20,25]$.

It is interesting to note that uptakes of $\mathrm{NO}_{3}^{-}$in the subcanopy are slightly higher than those in the top-canopy in summer and autumn (Fig. 5). The high temperature and humidity and dense canopy accelerate the nitrification of $\mathrm{NH}_{4}^{+}$[44]. The mobility of $\mathrm{NO}_{3}^{-}$via water solution in the soil facilitates its absorption by plants. Nitrogen uptake rate is more a function of demand for $\mathrm{N}$ from the shoot rather than of the nutrient concentration at the root surface $[3,43,44,47]$. Most plants grow better with high content of $\mathrm{NO}_{3}^{-}$and a number of studies have shown that plant growth may be enhanced with a mixed supply of $\mathrm{NH}_{4}^{+}$and $\mathrm{NO}_{3}^{-}[3,8]$. The percentage of deposited $\mathrm{N}$ which is taken up by the canopies is higher in young, fast growing stands, which have a high $\mathrm{N}$ requirement, compared to that of old and poorly growing stands [30]. Moreno et al. [32] reported the large absorption of nitrogen in the form of $\mathrm{NO}_{3}^{-}$by the canopies during growing seasons in central-western Spain.

\subsection{Uncertainty}

Stemflow was considered zero in our present study. The contribution of stemflow to the total flux, in general, is less than $10 \%[10,22]$. The estimates of canopy exchange via throughfall measurements are, therefore, to be underestimated or overestimated. Draaijers et al. [9] estimated that the uncertainty in throughfall fluxes used for deposition estimates, when made under ideal circumstances with the best available techniques, was about $40 \%$. Therefore, the uncertainties of calculated throughfall and sub-throughfall in the Shaoshan forest study will be slightly higher than that value because of the seasonality and the unevenly distributed rainfall, ranging between 40 to $50 \%$. The assumption in the canopy budget model is that $\mathrm{Ca}^{2+}, \mathrm{Mg}^{2+}$, and $\mathrm{K}^{+}$are deposited with equal efficiency to $\mathrm{Na}^{+}$, which may cause the underestimates of $\mathrm{Ca}^{2+}$ and $\mathrm{Mg}^{2+}$ and the overestimate of $\mathrm{K}^{+}[12,46]$. Draaijers et al. [11], Zeng 
et al. [46], and Zhang et al. [47] report that the mass median diameters of hydrated ions of $\mathrm{Ca}^{2+}$ and $\mathrm{Mg}^{2+}$ are larger than that of $\mathrm{Na}^{+}$, but that of $\mathrm{K}^{+}$is smaller than $\mathrm{Na}^{+}$, which may result in the underestimation of the dry deposition and the overestimation of the canopy leaching of base cations using the canopy budget model compared with the actual fluxes. The seasonal syntheses of data based on the three-year observations may reduce the yearly variability and increase the accuracy to examine the dynamics of nutrients in forest ecosystems.

Acknowledgements: The study was financially supported by the Natural Foundation for Distinguished Young Scholars (Grant No. 50225926, 50425927), the Doctoral Foundation of Ministry of Education of China (20020532017), the Teaching and Research Award Program for Outstanding Young Teachers in Higher Education Institutions of MOE, P.R.C. (TRAPOYT) in 2000 and the National 863 High Technology Research Program of China (2004AA649370). We thank the anonymous reviewers and the editor, Prof. Gilbert Aussenac, for their constructive comments and helpful annotation. We also thank Dr. David Moncoulon (Laboratoire des Mécanismes et Transferts en Géologie (LMTG), CNRS, France) for his help in French.

\section{REFERENCES}

[1] Balestrini R., Tagliaferri A., Atmospheric deposition and canopy exchange processes in alpine forest ecosystems (northern Italy), Atmos. Environ. 36 (2001) 6421-6433.

[2] Baumler R., Zech W., Impact of forest thinning on the throughfall of mountain forest ecosystems in the Bavarian Alps, Forest Ecol. Manage. 95 (1997) 243-251.

[3] Barber S.A., Nutrient uptake by plant roots growing in soil, in: Barber S.A. (Ed.), Soil nutrient bioavailability, 2nd ed., John Wiley \& Sons, New York, USA, 1994, pp. 85-109.

[4] Bredemeier M., Forest canopy transformation of atmospheric deposition, Water Air Soil Pollut. 40 (1988) 122-138.

[5] Bruijnzeel L.A., Waterloo M.J., Proctor J., Kuiters T., Kotterink B., Hydrological observations in montane rain forests on Gunung Silam, Sabah, Malaysia, with special reference to the 'Massenerhenbung' effect, J. Ecol. 81 (1993) 145-167.

[6] Campo J., Maas J.M., Jaramillo V.J., Yrizar A.M., Calcium, potassium and magnesium cycling in a Mexican tropical dry forest ecosystem, Biogeochemistry 49 (2000) 21-36.

[7] Cappellato R., Peters N.E., Dry deposition and canopy leaching rates in deciduous and coniferous forests of Georgia Piedmont: An assessment of regression model, J. Hydrol. 169 (1995) 131-150.

[8] Christ M., Zhang Y., Likens G.E., Driscoll C.T., Nitrogen retention capacity of a northern hardwood forest soil under ammonium sulfate additions, Ecol. Appl. 5 (1995) 802-812.

[9] Draaijers G.P.J., Erisman J.W., Van Lee Uwen N.R.M., Canopy exchange processes at the Spculder forest, Report No. 722108004 , National of Public Health and Environment Protection, Bilthoven, The Netherlands, 1994, 172-235.

[10] Draaijers G.P.J., Erisman J.W., A canopy budget model to assess atmospheric deposition from throughfall measurement, Water Air Soil Pollut. 85 (1995) 2253-2258.

[11] Draaijers G.P.J., Erisman J.W., Spranger T., Wyers G.P., The application of throughfall measurements for atmospheric deposition monitoring, Atmos. Environ. 30 (1996) 3349-3361.
[12] Draaijers G.P.J., Erisman J.W., Van Leeuwen N.F.M., Römer F.G., Te Winkel B.H., The impact of canopy exchange on differences observed between atmospheric deposition and throughfall fluxes, Atmos. Environ. 31 (1997) 387-397.

[13] Draaijers G.P.J., Ivons W.P.F., Bleuten W., Atmospheric deposition in forest edges measured by monitoring canopy throughfall, Water Air Soil Pollut. 42 (1998) 129-136.

[14] Edmonds R.L., Thomas T.B., Rhodes J.J., Canopy and soil modification of precipitation chemistry in a temperate rain forest, Soil. Sci. Soc. Am. J. 55 (1991) 1685-1693.

[15] Eilers G., Brumme R., Maztner E., Above-ground N-uptake from wet deposition by Norway spruce (Picea abies Karst.), For. Ecol. Manage. 51 (1992) 239-249.

[16] Erisman J.W., Mols H., Fonteijn P., Geusebroek M., Draaijers G., Bleeker A., van der Veen D., Field intercomparison of precipitation measurements performed within the framework of the Pan European Intensive Monitoring Program of EU/ICP Forest, Environ. Pollut. 125 (2003) 139-155.

[17] Fan H.B., Hong W., Ma Z., Waki K., Acidity and chemistry of bulk precipitation, throughfall and stemflow in a Chinese fir plantation in Fujian, China, For. Ecol. Manage. 122 (1999) 243-248.

[18] Fan H.B., Hong W., Estimation of dry deposition and canopy exchange in Chinese fir plantations, For. Ecol. Manage. 30 (2001) 99107.

[19] Hanson P.J., Lindberg S.E., Dry deposition and plant assimilation of gases and particles, Atmos. Environ. 16 (1991) 889-910.

[20] Hansen K., In-canopy throughfall measurements of ion fluxes in Norway spruce, Atmos. Environ. 30 (1996) 4065-4076.

[21] Hamburg S.P., Lin T.C., Throughfall chemistry of an ecotonal forest on the edge of the Great Plains, Can. J. For. Res. 28 (1998) 14561463.

[22] Larssen T., Xiong J., Vogt R.D., Seip H.M, Liao B., Zhao D., Studies of soils, soil water and stream water at a small catchment near Guiyang, China, Water, Air Soil Pollut. 101 (1998) 137-162.

[23] Lindberg S.E., Bredemeier M., Schaefer D.A., Qi L., Atmospheric concentrations and deposition of nitrogen and major ions in conifer forests in the United States and Federal Republic of Germany, Atmos. Environ. 24A (1990) 2207-2220.

[24] Lin T.C., Hamburg P.H., King B., Hsia Y.J., Spatial variability of throughfall in a subtropical rain forest in Taiwan, J. Environ. Qual. 26 (1997) 172-180.

[25] Lin T.C., Hamburg S.P., King H.B., Hsia Y.J., Throughfall Patterns in a subtropical rain forest of Northeastern Taiwan, J. Environ. Qual. 29 (2000) 1186-1193.

[26] Lin T.C., Hamburg S.P., Hsia Y.J., Base cation leaching from the canopy of a subtropical rainforest in northeastern Taiwan, Can. J. For. Res. 31 (2001) 1156-1163.

[27] Lovett G.M., Reiners W.A., Olson R.K., Factors controlling throughfall chemistry in a balsam fir canopy: a modeling approach, Biogeochemistry 8 (1989) 239-264.

[28] Lovett G.M., Lindberg S.E., Dry deposition and canopy exchange in a mixed oak froest as determined by analysis of throughfall, J. Appl. Ecol. 21 (1984) 1013-1027.

[29] Matzner E., Deposition/canopy interactions in two forest ecosystems of Northwest Germany, in: Gerogii H.W. (Ed.), Atmospheric pollutants in forest areas, D. Reidel Publ. Dorecht, Holland, 1986, pp. 247-262.

[30] Miller B.D., Hawkins B.J., Nitrogen uptake and utilization by slowand fast-growing families of interior spruce under contrasting fertility regimes, Can. J. For. Res. 33 (2003) 959-966. 
[31] Morrison I.K., Foster N.W., Nicholson J.A.M., Influence of acid deposition on element cycling in mature sugar maple forest, Algoma, Canada, Water, Air Soil Pollut. 61 (1992) 243-252.

[32] Moreno G., Gallardo J.F., Bussotti F., Canopy modification of atmospheric deposition in oligotrophic Quercus pyrenaica forests of an unpolluted region (central-western Spain), For. Ecol. Manage. 149 (2001) 47-60.

[33] Nich A.C., Kawi B., Wlodek T., Modeling rainfall and canopy controls on net-precipitation beneath selectively-logged tropical forest, Plant Ecol. 153 (2001) 215-229.

[34] Piirainen S., Finér L., Starr M., Deposition and leaching of sulphate and base cations in a mixed boreal forest in Eastern Finland, Water Air Soil Pollut. 131 (2002) 185-204.

[35] Prescott C.E., The influence of the forest canopy on nutrients cycling, Tree Physiol. 22 (2002) 1193-1200.

[36] Puckett L.J., Estimation of ion sources in deciduous and coniferous throughfall, Atmos. Environ. 24A (1990) 545-555.

[37] Raat K.J., Draaijers G.P.J., Schaap M.G., Tietema A., Verstraten J.M., Spatial variability of throughfall water and chemistry and forest floor water content in a Douglas fir forest stand, Hydrol. Earth Sys. Sci. 6 (2002) 363-374.

[38] Reynolds B., Estimating the total deposition of base cations from throughfall measurements, Sci. Total Environ. 180 (1996) 183-186.

[39] Turner D.P., Van Broekhuizen H.J., Nutrient leaching form conifer needles in relation to foliar apoplast cation exchange capacity, Environ. Pollut. 75 (1992) 259-263.

[40] Xu X.N., Wang Q., Hirata E., Precipitation partitioning and related nutrient fluxes in a subtropical forest in Okinawa, Japan, Ann. For. Sci. 62 (2005) 245-252.
[41] Ulrich B., Interactions of forest canopies with atmospheric constituents: $\mathrm{SO}_{2}$, alkali and earth alkali cations and chloride, in: Ulrich B., Pankrath J. (Eds.), Effects of accumulation of air pollutants in forest ecosystems, D. Reidel Publishing, Dordrecht, The Netherlands, 1983, pp. 33-45.

[42] Ullmar N., Acid deposition and throughfall fluxes of elements as related to tree species in deciduous forests of south Sweden, Water, Air Soil Pollut. 60 (1991) 209-230.

[43] Van Breemen N., Berrough P.A., Velthors E.J., van Dobben H., De Wit T., Ridder T.B., Reinjinders H.F.R., Soil acidification from atmospheric ammonium sulphate in forest canopy throughfall, Nature 199 (1982) 548-550.

[44] Wilson E.J., Foliar uptake and release of inorganic nitrogen compounds in Pinus sylvestris L. and Picea abies Karst. New Phytol. 120 (1992) 407-416.

[45] Zhao D.W., Hans M.S., Assessing effects of acid deposition in southwestern China using the MAGIC model, Water Air Soil Pollut. 60 (1991) 83-97.

[46] Zeng G.M., Zhang G., Huang G.H., Jiang Y.M., Liu H.L., Exchange of $\mathrm{Ca}^{2+}, \mathrm{Mg}^{2+}$ and $\mathrm{K}^{+}$and the uptake of $\mathrm{H}^{+}, \mathrm{NH}_{4}^{+}$for the canopies in the subtropical forest influenced by the acid rain in Shaoshan forest located in central south China, Plant Sci. 168 (2005) 259-266.

[47] Zhang G., Zeng G.M., Jiang Y.M., Yao J.M., Huang G.H., Jiang X.Y., Tan W., Zhang X.L., Zeng M., Effects of weak acids on canopy leaching and uptake processes in a coniferous-deciduous mixed evergreen forest in central-south China, Water Air Soil Pollut. 172 (2006) 39-55. 